\title{
Delegation of Authority for Secondary Education Management Aspects of Regional Assets / Property at the East Java Provincial Education Office
}

\author{
Siswoko Andianto, Widyawati Boediningsih, \\ Faculty of Law, Narotama University Surabaya \\ E-mail: siswoko_andianto@ymail.com and widyawati@narotama.ac.id
}

\begin{abstract}
After the enactment of the Law 23/2014 as the new regional government law (UU Pemda), the government formulates new regulations related to changes in the concurrent division of government affairs between the central government and regional governments. The purpose of this study is to describe the implementation of the transfer of authority to manage secondary education from the point of view of the aspect of management of regional assets / assets in the East Java provincial education office and the problems in the transfer of authority to manage secondary education from the point of view of the aspect of managing regional assets / property in the provincial education office. East Java. Nornative empirical research methods. Basically, it is an amalgamation of a normative legal approach with the addition of various empirical elements. The result of the research is that the Field Verifier Team and the Regional Assistance Team have a central role in overcoming problems related to the transition in the Secondary Education sector, namely by re-correcting the results of data collection and confirming the results of data collection both to the Surabaya City education office concerned and to the Education Office. East Java Province. All local governments, both provincial and district / city, must implement this policy. One of the regions that has also implemented this policy is the Province of East Java. The East Java Provincial Government has specifically implemented the policy of transferring secondary education management as mandated by Law no. 23 of 2014 through the East Java Provincial Education Office.
\end{abstract}

Keywords: Law 23 of 2014, Delegation, Secondary Education, East Java Provincial Government.

\section{INTRODUCTION}

Transfer of authority for the management of secondary education applies to all regions, including provincial and city governments. One of the provincial governments that has transferred the authority to manage secondary education is East Java Province. The East Java Provincial Government carried out the implementation of a policy on the transfer of authority for the management of secondary education in accordance with Law no. 23/2014 through the East Java Provincial Education Office, which is authorized to administer the education sector. The delegation of secondary education authority from the city to the province poses challenges for both the city government and the provincial government. The challenge of the East Java Provincial Government is the number of high school schools and the range of control of the East Java Provincial Education Office which is large and spreads in 38 cities. Therefore, for the smooth management of secondary education in 38 cities, the East Java Provincial Government has established Education Offices in several regions (Safa'at \& Number, 2016).

The delegation of authority for the implementation of the transfer of Secondary Education Management carried out by the East Java Provincial Government, one of which is in the city of 
Surabaya. The Surabaya City Government must hand over the management of secondary education to the East Java Provincial Government. The quality of education management in Surabaya City, especially secondary education, is quite good when compared to other cities in the East Java region. The indications include: eliminating the cost of education; improving the quality of student education, quality of teachers, education services through various programs and services that are quite effective and efficient. (Presentation from the Surabaya City Education Office, 2017). The authority to manage secondary education, in this case Senior High Schools and Vocational High Schools in the City of Surabaya to the East Java Provincial Government, must continue to be implemented, in accordance with Law No. 23/2014 concerning Regional Government which is national in nature (SN Damayanti, 2017).

Regional property is also regulated in Government Regulation no. 27/2014 concerning State / Regional Property Management. The contents of which are about the Management of Regional Property (INDONESIA, 2014). In Government Regulation no. 27/2014 concerning State / Regional Property Management, that every manager of state / regional property must be responsible for the obligation to know in detail every report and management of state / regional property. Many managers of regional property have difficulty managing goods based on regulations, so that inappropriate reporting of goods management by local governments can cause regional losses. Government Regulation No. 27/2014 concerning Management of Regional Property, the implementation must be in accordance with Article 3 paragraphs 1 and 2, namely that management must be carried out based on the principles of functionality, transparency, accountability, efficiency, and legal certainty and value. The implementation of managing regional assets, which must be considered by local governments is in terms of asset planning, asset procurement, and asset control (Aira, 2015).

The problem that often occurs in the management of regional property in the local government is that the laws and regulations in the management of regional property have not been properly implemented which results in the procurement of goods that are not in accordance with the main tasks and functions of the Regional Apparatus Work Unit, the use of goods. regional property that is not in accordance with the stipulation of use, damaged and obsolete goods are left alone, incomplete administration of regional assets so that it is very risky to be lost and stolen, goods that are not preserved are taken over by other parties, administrative reports of regional property by the Regional Apparatus Work Unit often late, goods that are not returned to the Regional Apparatus Work Unit by retired officials, the low performance of regional administrators and depositors of assets to maintain and care for regional property plus less competent regional apparatus. 
This work is licensed under a Creative Commons Attribution-ShareAlike 4.0 International License

In the implementation of Secondary Education Management in Surabaya, which was transferred by the East Java Provincial Government, it was suspected that it caused several problems. There are two things that are in the spotlight, namely the equal distribution of the province's ability to provide quality education services and budget capacity. The Pemprov's heavy task is to provide a quality education service standard, at least the same as the previous city. Gradually there are policy steps to improve the quality of education. Providing educational services is certainly not easy because the scope of high schools handled by the provincial government has become wider.

\section{RESEARCH METHOD}

In general, there are two research models, namely normative law and empirical law. According to Marzuki, normative legal research is "a step to find a rule of law, legal principles, and legal doctrine in order to answer the legal issues at hand". Nornative research fully uses secondary data, so in the preparation of a tentative theoretical framework is left out, but the preparation of a conceptual framework is absolutely necessary, so in compiling a conceptual framework a formulation of legislation is needed (Nurhayati, 2013).

The empirical research method is a legal research method that functions to see the law in a real sense of how the law works in society. In this study, examining people in relation to life in society, the empirical legal research method is said to be sociological research. This type of research in this writing is a non-empirical research method. Basically, it is an amalgamation of a normative legal approach with the addition of various empirical elements. The normative-empirical method regarding the implementation of normative legal provisions (Laws) in action on certain legal events in society.

\section{RESULTS AND DISCUSSION}

\section{Legal Aspects Transfer of Secondary Education Asset Management Authority The}

Problem of transferring authority to manage Secondary Education Assets from the Surabaya City Government to East Java Province can be viewed from a legal aspect in the form of rights and obligations or local government duties and implementation based on statutory regulations. Therefore, with the transfer of authority to manage Secondary Education Assets, as of this writing, there are no provisions in statutory regulations or technical guidelines that regulate the procedures for their implementation. However, systematically this material falls within the scope of the management of regional property. To see the rights and obligations of the Surabaya City Government and the province in the transfer of authority to manage secondary education assets in a comprehensive manner, it can be seen from the Circular of the Minister of Home 
This work is licensed under a Creative Commons Attribution-ShareAlike 4.0 International License

Affairs No. 120/5935 / SJ Year 2015 and the regulations governing the management of regional property. Based on a Circular of the Minister of Home Affairs, the rights and obligations of city and provincial governments relating to inventory, verification, and coordination tasks related to asset transfer, as well as the preparation of handover notes (Kahfi, 2016).

Provisions regarding the management of goods are regulated in Government Regulation No.27 / 2014 concerning State Property Management and Regulation of the Minister of Home Affairs No. 19/2016 on Guidelines for the Management of Regional Property (Permendagri No.19/2016). In principle, the transfer of assets from the Surabaya municipal government to the province can be equated with a grant. Grant is the transfer of ownership of goods from the central government to regional governments, between regional governments, or from local governments to other parties, without obtaining compensation. One of the grants for regional property is carried out with consideration for the benefit of education (Panjaitan \& Budi Gutami, 2017).

One example of implementing the transfer of authority to manage the education sector by means of a grant is in East Java Province. Broadly speaking, these activities include socialization, inventory, evaluation, the final stage is data reconciliation activities which are the stages of finalizing data objects that will become objects of handover ( Indonesia, 2003). Some of the steps taken by the East Java Provincial Government were as follows:

a. The Provincial Government has carried out the socialization of Law no. 23/2014 and the application of the Minister of Home Affairs Circular No. 120/5935 / SJ dated 16 October 2015.

b. Implementation of an inventory of personnel data, funding, infrastructure and facilities, and documents (P3D) of SMA / SMK in the city of Surabaya through secondary data.

c. Arrangement of P3D materials / materials as the basis for inventory steps and data verification at schools at the education unit level and the Surabaya City Education Office.

d. Inventory and verification of P3D data at public high schools / vocational high schools and the Surabaya City Education Office carried out by Regional Facilitators and Field Verifiers. Regional assistants are tasked with accompanying and providing direction in the field to the Surabaya City Education Office concerned, in recording objects whose management will be transferred to the Provincial Education Office East Java. The field verifier is tasked with receiving the results of data collection and re-checking or evaluating data on objects of secondary education that will be transferred to the office. 
e. Secondary Education Asset Data Reconciliation which will be transferred from the Surabaya City Government to the East Java Provincial Government.

The Asset Inventory Team coordinates with the Education Office and the Regional Financial and Asset Management Agency in order to evaluate and reconcile asset data to be submitted to the province.

1) Coordinate with the regional government of Surabaya City in the context of verification and reconciliation of data on secondary education assets that will be transferred from the City of Surabaya to the province.

2) Preparation of budget allocations for asset transfers.

3) Signing a memorandum of understanding and the Minutes of Asset Handover.

4) Recording assets received from the City of Surabaya in the financial statements.

Apart from the above obligations, in principle, the right of the provincial government is to obtain asset data along with supporting documents that are valid both administratively and physically in the context of the process and management of the assets to be transferred. Meanwhile, the district government has the right to receive assistance or assistance from the province in order to verify asset data to obtain valid data.

\section{Data Validity and Transfer Status of Asset Ownership Rights.}

The validity of asset data is a determining part for the transfer of assets. The validity relates to the accuracy of the data accompanied by supporting documents / evidence (Istiningsih, 2019). For example, fixed assets in the form of land must be accompanied by clear proof of ownership / certificate of land or land that has been certified but is not in the name of the regional government, including clarity of the location of the land. The accuracy of the administrative and physical aspects of an asset to be transferred becomes the basis for the object of asset transfer between the Surabaya Government and the province as outlined in the Handover Report. The validity of the asset data to be transferred has implications for the accuracy of recording assets on the balance sheet in the financial statements of each government. area.

Asset Handover Official Report is a document of handing over of goods as evidence of the transfer and transfer of rights / ownership of the asset from the donor to the recipient of the asset. Juridically, these assets were transferred from the Surabaya municipal government to the provincial government. The transfer of secondary education assets from the city of Surabaya to the province has consequences for both parties in the framework of recording the financial statements and the write-off of assets by the city of Surabaya. For the City of Surabaya, the basis for asset deletion is not only the Handover Event News, but it is stipulated with the approval or decision of the regional head as stipulated in Permendagri No.19/2016. The Technical Bulletin of Government Accounting Standards No.15 on Accrual-Based Fixed Asset Accounting also regulates that for fixed assets the 
This work is licensed under a Creative Commons Attribution-ShareAlike 4.0 International License

grant is taken out of the balance sheet when the minute of grant handover by the entity is issued as a follow-up to the grant approval.

Thus, the Handover Minutes and the decision to write off assets from the City of Surabaya are supporting documents for the transfer of Secondary Education Assets from the City of Surabaya to the province.

\section{Transfers of Fixed Assets in Relation to Recording or Recognition of Fixed Assets.}

Assets are government assets that must be recorded in the financial statements of local governments, in particular, fixed assets are a significant part of government assets in the balance sheet presentation. Fixed assets are tangible assets that have a useful life of more than twelve months to be used, or intended to be used, in government activities or utilized by the general public (PAMUNGKAS, nd). Fixed assets include land, equipment and machinery, buildings and buildings, roads, irrigation, networks, other fixed assets, and construction in progress (PAMUNGKAS, nd).

The delivery of fixed assets by means of a handover report has implications for the recognition and recording of the transfer of fixed assets from the Surabaya City Government to the province. From the accounting side, the recognition of an inheritance is very reliable if the inheritance has always been received or given over its ownership rights and / or when its ownership is transferred. If the acquisition of an inheritance has not been supported by legal facts, it is due to the existence of a mandatory administrative process, such as the purchase of land which is still required to complete the sale and purchase process (deed) as well as a certificate of ownership at the competent authority, so that the legacy must always be recognized when there are facts that the ability of the inheritance has always been transferred, for example, payments have been made and the ability to obtain land certificates in the name of the former owner. Legacy is always recognized when future economic properties can be obtained and its value can be measured reliably.Transfer of Authority for Secondary Education Management to the Provincial Government of East Java.

In connection with the passage of this law with the decentralization arrangement, not all decentralized government affairs can be implemented practically with good results by the Surabaya Government, or vice versa by the provincial government. The aim of this policy, on the other hand, is to strive for equal distribution of learning at the provincial level, but it raises some of the implications that the community or the Surabaya government will accept, who feel that they are actually very good at managing learning and the properties that have helped the people of Surabaya. Because this decentralization has the potential to create gaps in the management of government affairs both administratively and financially from the regions, therefore the central government can control which government affairs can be decentralized and given its authority to 
This work is licensed under a Creative Commons Attribution-ShareAlike 4.0 International License

the provincial government or the Surabaya Government with various considerations as part of decentralized politics.

Launching from the online newspaper Suara Surabaya, the Governor of East Java commented that school management is about how to produce a quality school where learning must have a uniform or equal character between regions and be comprehensive in all regions. Soekarwo did not give priority to the lawsuit by the people of Surabaya who wanted the management of SMA and the equivalent to be returned to the Surabaya Government so that operational costs could be free again, he emphasized that how the implementation of secondary learning in East Java province can be comprehensive and uniform so that there are no areas that are superior or behind the quality of education .

This policy of transferring the management of secondary education is a step in an effort to equalize the quality of education, especially secondary and special schools whose management authority lies at the provincial level (Puteri, 2018). For some regions that have not been able to manage secondary education properly, of course this policy can ease the duties of the regional government so that they can focus on their own authority, but for some regions that feel they are able to manage secondary education, of course they will object to the transfer of authority for education management policy. this medium.

From the policy on the transfer of authority to the management of secondary education, researchers categorized several implications that arise in the field, including administrative impacts, political impacts, and budget / economic impacts. The administrative impact of the transfer of authority is the birth of bureaucratic and coordination procedures which are considered by some parties to be more complicated than when the authority was held by the Surabaya Government, because for matters of managing SMA and the equivalent, up to school assets, staff, and the budget which have now been transferred to The Provincial Government of East Java, so the required actions take a more complicated bureaucratic and coordination process and will tend to take longer to handle. As complained by Martadi, the Head of the Surabaya City Education Council, he considered that this policy of transferring authority to management of SMA and its equivalents made the City of Surabaya less profitable because the policy was not pro-Surabaya residents. According to him, in terms of handling sensitive issues involving high school students or equivalent in the city of Surabaya, the Surabaya Government actually has excellent potential and ability to handle it, but the Surabaya Government is obstructed and cannot directly intervene because of the authority that does not become the authority of the Surabaya Government.

A similar opinion was also expressed by several teachers and deputy head of SMA in Surabaya who were interviewed by the researcher, they felt that it was better for education management to be under the Surabaya Government than under the East Java Provincial 
This work is licensed under a Creative Commons Attribution-ShareAlike 4.0 International License

Government. They interpreted that the management by the Surabaya City Government was very appropriate to the conditions and needs of the school, especially with the problem of financing that was borne by the Surabaya City Government as a whole.

In fact, the real goal of this policy is to advance the quality of secondary education in all regions down to the provincial level with management under the provincial government. With uniform regulations or policies, it is hoped that no more regions will be left behind in matters of secondary education quality. In this policy, the main focus of the implementation of secondary education by the East Java Provincial Government is to eliminate the stigma of "favorite school", such as increasing the quota by $10 \%$ for prospective students who come from outside the city or outside the region who wish to enter, which was previously the Surabaya City Government. only giving a quota of only $1 \%$ because they want to give priority or opportunity for native Surabaya residents to enter high school in the city of Surabaya.

After the judicial review lawsuit was rejected by the Constitutional Court, the Surabaya City Government and the Surabaya City Regional People's Representative Council did not reach an agreement regarding the transfer of authority for the management of secondary education so that the Surabaya City Government could no longer help its citizens in terms of financing high school and equivalent student education in the City of Surabaya because it was hindered by problems. between the Surabaya City Government and the Surabaya City Regional People's Representative Council who did not reach an agreement because of differing opinions when the Regional People's Representative Council had a pragmatic mindset how the financing of secondary education could be covered by the Surabaya Regional Budget, while the Surabaya City Government wanted its management to be returned to the Surabaya Government .

As in the statement of the members of Commission D DPRD Surabaya which implies differences of opinion between members of the legislature and the Surabaya City Government when interviewed by researchers. He stated that the Surabaya City Government wanted to be able to intervene by providing space to manage the implementation of SMA and equivalent education in the City of Surabaya, but when the law spoke that the authority to manage SMA and equivalent education was not returned to the Surabaya Government, immediately the attitude of the City Government of Suarabaya seemed hands-off. from the struggle of the Surabaya Regional House of Representatives who want the operational assistance for high school level schools and as close as possible to be provided by the Surabaya Government.

Members of the Surabaya City Regional People's Representative Council insist on ensuring that high school and equivalent education in the City of Surabaya can remain free of charge outside of its management carried out by the Surabaya City Government or the East Java Provincial Government. According to him, if assistance in the form of a program cannot be used 
This work is licensed under a Creative Commons Attribution-ShareAlike 4.0 International License

to finance the operations of SMA and equivalents in the City of Surabaya, the City Government can use assistance in the form of a social assistance formula that can be given directly to students and not through schools or the East Java Provincial Government. Another way that the Surabaya City Government can continue to help pay for children's school fees in Surabaya is to use CSR funds, which are quite a lot of CSR funds in Surabaya, according to Reni Astuti.

From his statement, it can be seen that the legislative members have a pragmatic mindset, which emphasizes the desire to help Surabaya residents in terms of education funding for high schools and equivalents in the city of Surabaya, because they do not want a decrease in the quality of education in the city of Surabaya outside of matters of management authority. held by the Surabaya City Government or the East Java Provincial Government. According to him, financial assistance could still be given to high school students and the equivalent without having to allocate it in the form of BOPDA. This assistance can be given to the student concerned instead of the Surabaya City Government being unable to budget for assistance in the form of the BOPDA program.

On the other hand, in the 2017 Surabaya APBD, the Surabaya City Government has allocated a BOPDA budget of approximately 200 billion Rupiah which must be returned to the regional treasury because the Surabaya City Government cannot utilize the BOPDA budget because the budget is a program budget. At that time the city government still included the BOPDA budget to finance the free school program for secondary education because at that time the government had hopes that the discretionary application they submitted to the Constitutional Court so that the management authority of astas and equivalent secondary schools could be returned to the Surabaya Government. When the Mayor of Surabaya has optimism that there is still a chance for the Surabaya City Government to gain discretion and take over the management of secondary and equivalent education in the City of Surabaya again, Risma as the Mayor of Surabaya becomes an expert witness in the trial at the Constitutional Court.

However, in 2019, the Surabaya City Government will maintain its consistency in allocating $20 \%$ of its regional budget for the education sector by diverting the budget for improving school infrastructure, developing the quality of teaching personnel, and establishing non-formal schools at several points in the City of Surabaya.

\section{Regional Owned (Asset) Secondary Education in East Java Province}

Law No. 23/2014 divides government affairs into 3 affairs, namely absolute government affairs, concurrent government affairs, and general government affairs. Absolute governmental affairs are government affairs which fully fall under the authority of the central government, concurrent government affairs are government affairs divided between the central government and the provincial and regional governments of the City of Surabaya, and general government 
This work is licensed under a Creative Commons Attribution-ShareAlike 4.0 International License

affairs are government affairs which fall under the authority of the president as head of government. Concurrent governmental affairs that are transferred to the regions are the basis for implementing regional autonomy.

The implementation of Law Number 23/2014 has led to changes in local government organizations in Indonesia. This change occurred in connection with the transfer of authority from the Surabaya City Government to the provincial government in the sub-affairs of secondary education management, forestry affairs, human resources affairs, marine and fisheries affairs, terminal management, metrological authority and manpower authority. This law is the legal basis for the transfer of authority over the management of secondary education from the Surabaya City Government to the provincial government. The law states about the division of government affairs in terms of education management between the central, provincial and city governments of Surabaya. The management of SMA management is in the hands of the provincial government, while the Surabaya City Government only handles elementary and junior high schools (Puteri, 2018).

According to Meydiandra EP as Head of the Regional Goods Storage and Administration Division of East Java Province, specifically on the transfer of authority for secondary education and special education, there was a transfer of assets from approximately 218 State Senior High Schools and 84 Public Vocational High Schools from the Surabaya City Government in East Java Province to East Java Provincial Government. The impact of the transfer of functions / authorities on the management of regional assets, among others, is the improvement in the management of regional assets.

According to Wayan Purwanajata, Head of the Subdivision of Monitoring, Evaluation, and Compilation of Regional Goods Accounts at the Regional Equipment and Assets Bureau of the Regional Secretariat of East Java Province, stated that the implementation of this process of transfer of authority was not accompanied by special rules or government regulations as a derivative of Law No. While the implementation of the provisions of this law is given a deadline, because in Article 404 of Law 23/2014 on Regional Government it is stated that the handover of personnel, funding, facilities and infrastructure, as well as documents as a result of the division of government affairs between the central government, provincial regions and The area of Surabaya City which is regulated by virtue of this law is carried out no later than 2 (two) years from the time this law is promulgated. As a result, local governments are confused when implementing a number of provisions in the law.

Based on the provisions of the Regulation of the Minister of Home Affairs Number 19 of 2016 concerning Guidelines for the Management of Regional Property Chapter X Article 329 paragraphs 1 and 2, it is stated that regional property can be transferred by: 
a. Sales;

b. Exchange;

c. Grants, and

d. Local government equity participation.

The implementation of the transfer of assets this time follows the provisions of Law Number 23/2014 concerning Regional Government, the emphasis is on Article 404. As a followup, the central government in this case the Minister of Home Affairs issued a Circular of the Minister of Home Affairs Number: 120/253 / SJ dated 16 January 2015 Regarding the Implementation of Government Affairs after the enactment of Law Number 23/2014 concerning Regional Government, then the second Circular of the Minister of Home Affairs No.120 / 5935 / SJ dated 16 October 2015 concerning the Acceleration of Implementation of Transfer of Affairs based on Law No. 23/2014 on Regional Government. Especially in East Java Province, the East Java regional government has issued the Governor of East Java Decree Number G / 442 / B.II / HK / 2015 dated 10 September 2015 concerning the Formation of an Inventory Team for the Submission of Personnel, Funding, Facilities and Infrastructure and Documents from the District / Cities in East Java Province.

The Transitional Process of Management of Regional Property in the form of Land in the Education Sector of State High School / Vocational Schools in East Java Province

Article 404 of Law Number 23/2014 concerning Regional Government states that the handover of Personnel, Funding, Facilities and Infrastructure, and Documents as a result of the division of government affairs between The Central Government, Provincial Regions and District / City Regions as stipulated in Law Number 23/2014 shall be implemented no later than two years from the promulgation of Law Number 23/2014. Then in the Circular of the Minister of Home Affairs Number 120/5935 / SJ dated 16 October 2015, it is stated that the process of Inventory of Personnel, Facilities and Infrastructure, Funding and Documents as a result of the transfer of concurrent government affairs will be carried out no later than March 31, 2016. The inventory of assets that will be transferred of authority from Surabaya City to the East Java Provincial Government must be completed before March 31, 2016. The

Coordinator of the P3D Transfer Team for the Regional Equipment \& Assets Bureau of East Java Province stated that in the process of transferring this authority, the Provincial Regional Equipment \& Asset Bureau was constrained by the absence of derivative regulations from Law Number 23/2014 as a specific rule or reference for this delegation process. In fact, when each law is implemented, there should be a derivative regulation, however, as of Law Number 23/2014, the central government has not issued a derivative regulation (PP). 
This work is licensed under a Creative Commons Attribution-ShareAlike 4.0 International License

The same thing was stated by Noer Oemarijati, Head of the City of Surabaya Assets, that in the implementation of this delegation of authority, the City of Surabaya is having difficulties because there are no special rules as a reference for the transfer of assets from the City of Surabaya to the province. The central government only issues a Circular of the Minister of Home Affairs so that the regional government in the implementation of the transfer of these assets is not supported by specific standard regulations.

At this time the government of East Java Province has reached the stage of collecting the supporting rights for the land in SMA in the city of Surabaya throughout East Java Province. Then all the original land rights in high schools in Surabaya City throughout East Java Province will be withdrawn by the East Java Provincial government during the handover process between the Surabaya Government (regents / mayors) throughout East Java Province and the regional government of East Java Province (governors). on October 2, 2016.

The handover process will be carried out in an official event regarding the signing of the minutes of handover of personnel, facilities and infrastructure and documents which will be attended by the Governor of East Java, regents / mayors throughout East Java Province, elements of the Ministry, and regencies. / city and Head of East Java Province High Prosecutor's Office and Head of District / City District Attorney Offices in East Java Province (R. Damayanti, 2012).

Meanwhile, the process of transferring the name of the high school certificate from the name of the local government of Surabaya City to the name of the provincial government or land registration in the name of the provincial government can be carried out by the provincial government when the process of transfer of authority has been completed, marked by the submission of all the rights pad owned by the Surabaya Government accompanied by an official report of the handover signed by the regent / mayor.

According to Mujahiddin as head of the East Java Regency National Land Agency office, argued that when he wanted to change his name or register a land certificate, the governor through the regional secretary made a statement that the land had indeed turned into an asset of the provincial government in this case East Java Province and Also these assets are not in any dispute so that an application letter is made to change the name of the Surabaya Government assets to become on behalf of the provincial government in this case the Province of East Java. Likewise for land that does not have a certificate to issue a certificate in the name of the provincial government, in this case the Province of East Java. When applying for the process of turning the names of district government assets into assets of the provincial government as well as the land certification process that is not yet certified, the following must be prepared:

a. Asset handover report;

b. Minutes of the waiver of rights from the City of Surabaya; 
This work is licensed under a Creative Commons Attribution-ShareAlike 4.0 International License

c. A statement letter from the governor through the regional secretary stating that the assets in question have transferred ownership from the assets of the City of Surabaya to the assets of the province and these assets have been recorded in the provincial asset book;

d. The basis of rights as proof of existing ownership;

e. Physical control statement signed by the regent / mayor and witnessed by at least 2 (two) witnesses for land for SMA / SMK that has not been certified;

f. After that the provincial government made a request for a name change to the local Surabaya City National Land Agency office to issue certificates or change other ownership data, and also registered uncertified lands (raw land) under the name of the provincial government.

The same was stated by the Head of Sub-Section for the Transfer of Rights to the City of Surabaya, which stated that considering that there were still many assets of government agencies that had not been registered, in order to guarantee legal certainty of land rights, government agencies needed to be given facilities and acceleration for government agencies that would register them. land, which is stated in the Circular of the Minister of Agrarian Affairs and Spatial Planning / Head of the National Land Agency Number: 1855 / 15.1 / IV / 2016 dated April 22, 2016 concerning Guidelines for the Implementation of Land Registration for Government Agencies.

Oki MP continued that after the signing of the report on the handover of assets based on the order of the law, the assets were legally transferred from the Surabaya Government to the provincial government. Where the stages are the Surabaya Government must first remove these assets from the SIMDA list of the Surabaya Government assets, then the assets are transferred to the SIMDA as assets of the provincial government. The next stage is based on the existing proof of ownership to register the application for its rights at the Surabaya City land office through the subsection work unit for land registration by government agencies and must meet the requirements according to Government Regulation No. 128 of 2015 and Government Regulation No. 1 of 2010.

Even though government agencies in the process of registering land have easy access, government agencies still have to pay attention to number 3 of the Circular of the Minister of Agrarian Affairs and Spatial Planning / Head of the National Land Agency Number: 1855 / 15.1 / IV / 2016 which states that the land being applied for must be instate Clean and Clear that there are no objections from other parties on land controlled (no dispute) or not in the occupation loccupatie by other parties and have been recorded in the inventory list of assets the government agencies concerned. 
This work is licensed under a Creative Commons Attribution-ShareAlike 4.0 International License

Wayan Purwanajata as Head of Subdivision of Monitoring, Evaluation, and Preparation of Regional Goods Balance at the Regional Equipment and Assets Bureau of the Regional Secretariat of East Java Province explained that this value was obtained from the Surabaya Government balance sheet which had been audited by the Supreme Audit Agency as of December 2015. So that the assets handed over by the Government This value in Surabaya does not reflect the actual condition. This is because there are still some assets that have not been included in their acquisition value, because these assets have not been recorded in the Surabaya Government SIMDA.

Likewise, specifically with regard to land assets, there are differences in the amount of land between land assets submitted and land data recorded in the balance sheets of each Surabaya Government in East Java Province. So that the value of assets, especially in land assets handed over to the Province of East Java, does not yet describe the true condition. This is because there are still land assets that have been acquired by the school but are not reported to the Education Office or the Regional Financial and Asset Management Agency in the City of Surabaya.

Until this writing was completed (October 2016), the Surabaya Government, which has reported in detail the land assets of Senior High Schools to the East Java Provincial Government, there are eight Surabaya Cities. Briefly displayed in the following table, and details are shown in the appendix. Indeed, many government assets do not have certificates, even the land assets that have been certified are not all in the name of the respective Surabaya City government, because there is still a certificate in the name of the Ministry of National Education or the Regional Office of Education and Culture but physically these assets has been controlled and has been used (Aira, 2015). So that during the process of changing the name or registering the land, the government must make a statement of physical control of the land parcel based on true information and the party making the statement is liable both civil and criminal if in the future there are elements of untruth in the statement and are willing to cancel the certificate. and processed by law according to applicable regulations.

At the time of the land registration process, government land was not as complex as community land. So that when applying for land registration for Senior High Schools that have not been certified to the National Land Agency, it is sufficient for the governor through the regional secretary to ensure that the land is indeed a provincial asset and is not in dispute. On the other hand, for a lost certificate, the local Surabaya Government must report it to the police. Next, the police will announce for 2 (2) consecutive months through newspapers, if there is no objection until the local Surabaya National Land Agency wants to issue a new certificate and when a new certificate is issued, the new certificate will include a statement reporting that The 
This work is licensed under a Creative Commons Attribution-ShareAlike 4.0 International License

old certificate is no longer valid, and if later the old certificate is found, it is obligatory to notify the certificate to the local National Land Agency office to make it deactivated.

Land certification or the process of transferring names is part of maintaining information called continuous recording. Because according to the purpose of land registration contained in Article 3 of Government Regulation Number 24 of 1997 concerning Land Registration, it is:

a. To provide legal certainty and legal protection to holders of rights over a land parcel, flat unit and other registered rights so that they can easily prove themselves as holders of the rights concerned;

b. To provide information to interested parties, including the government, so that they can easily prove themselves as holders of the rights concerned;

c. For the implementation of an orderly land administration.

On the other hand, Sumarja says in his book that what is meant by land registration is a series of activities that the government tries to continuously and orderly include collection, processing, bookkeeping, and physical and juridical presentation and maintenance, in the form of maps and records, overwriting the fields. land parcels and apartment units, listed the issuance of certificates as a message of the fact of their rights for land parcels for which there are already rights as well as ownership rights over flat units and certain rights that impose them.

Based on the description above, it can be concluded that the purpose of land registration is to share certainty on land objects, rights, and certainty of the subject. The number of cases that arise from land ownership to land registration is also to estimate all forms of disputes that may occur, so that by law the owner of the rights is obliged to register the land which is their right, so that there is no harm in the future, as stated in Article 4 paragraph 3 Government Regulation Number. 24/1997 concerning Land Registration which reads as follows: "In order to achieve an orderly administration of each land parcel and apartment unit, the transfer, assignment and abolition of rights to land parcels and ownership rights to apartment units must be registered".

Therefore, the rights to a plot of land must be registered at the local land office where the land is located. Besides being the obligation of the land owner, in this case the local government, land registration is also to implement Article 3 letter c of Government Regulation No. 24/1997 on Land Registration which reads: "Land registration aims to maintain orderly land administration".

So that by registering ownership of rights over the land parcels so that the owner has certainty, strength and legal protection of land ownership. In order to provide guarantees of legal certainty and protection, regarding the role, status of land so that there are no disputes and misunderstandings either affecting boundaries or who owns them, until the Basic Agrarian Law as a law which contains the main basics in the agrarian sector which is the basis for agrarian law 
This work is licensed under a Creative Commons Attribution-ShareAlike 4.0 International License

reform efforts to share legal certainty guarantees for citizens in using the earth, water, and space and natural resources listed therein for common welfare equitably. The objectives of the Basic Agrarian Law include ensuring legal certainty. In order to achieve this goal, the Basic Agrarian Law already controls land registration, which is in Article 19 paragraph (1) of the Basic Agrarian Law which reads: "To ensure legal certainty by the Government, land registration is held throughout Indonesia for legal certainty by the government, registration is held by the government. land in all regions of Indonesia according to the conditions stipulated by the Government Regulation. "

Meanwhile, related to the transfer of ownership as a result of the transfer of asset management, this can be implemented because it is a law order. Even though Article 37 paragraph (1) states that the transfer of land rights and property rights can only be registered if it is proven by deeds made by the competent PPAT according to the provisions of the prevailing laws and regulations. However, based on the Circular of the Minister of Agrarian Affairs and Spatial Planning / Head of the National Land Agency Number: 1855 / 15.1 / IV / 2016 dated April 22, 2016 concerning Guidelines for Land Registration for Government Agencies, so that government agencies in this case the East Java provincial government have a specificity (Lex Specialis Derogat Legi Generalis) and facilities in order to obtain rights and settle certificates for the lands which are its assets.

\section{Inventory and Transitional Object Data Verification Secondary Education}

Kegiatan Inventory and Data Verification P3D Secondary Education intended to get an idea of the conditions and mapping related data data- aspects of personnel, assets, and Financing Secondary Education in the city of Surabaya, so that the Provincial Education Department has base statistics that can be used as the basis for calculating the burden of secondary education budgeting comes from the Provincial Regional Expenditure Budget in the 2017 Fiscal Year, which is when the authority of Secondary Education has transferred to the Provincial Government.

The objectives of implementing the Secondary Education Sector P3D Data Inventory and Verification activities are

1. Clarification of personnel data (Educators and Education Personnel) and data on secondary education facilities at Senior High Schools in the city of Surabaya and other relevant institutions / work units;

2. Identification of the financing data for State Senior High Schools that have been taking place in the City of Surabaya (RAPBS for the last 3 years); 
3. Identification of financing data and copies of asset documents (certificates of asset ownership and personnel) which indicate the legality of the existence of assets or elements of public high school personnel, or other educational institutions / units.

The expected results from the P3D Secondary Education Data Inventory and Verification activities are:

1. Clarification of data on personnel, funding, infrastructure and facilities (educational assets), and documents in the field of secondary education based on temporary nominative data in senior high schools in the city of Surabaya;

2. Compiled data on Personnel, Funding, Infrastructure and Facilities, and Documents (P3D) in the field of Secondary Education in the latest 597 State Senior High Schools throughout East Java;

3. Mobilization of stakeholders at the Surabaya City Government level to participate in carrying out the inventory and verification of P3D Secondary Education data, which is built on the basis of mutual agreement regarding personnel data, as well as infrastructure and facilities (educational assets) to be submitted to the Provincial Government;

4. The compilation of the latest Nominative List of Personnel, Infrastructure and Facilities (assets) data and Financing Data, as the basis for calculating the burden or responsibility of the Provincial Government in 2017.

\section{CONCLUSION}

Based on the results of the research and data analysis that has been carried out, it can be concluded that the implementation of Law Number 23/2014 has led to changes in government organizations. This change occurred in connection with the transfer of authority from the Surabaya City government to the provincial government, one of which was the management of secondary education. This law is the legal basis for the transfer of management authority affairs for secondary education (SMA / SMK) from the Surabaya City government to the provincial government, whose emphasis is on Article 404 of Law Number 23/2014 concerning Regional Government.

The legal aspects of the transfer of authority to manage fixed assets from the Surabaya City Government include the rights and obligations or duties of each regional government and the legal status of asset transfer as referred to. In principle, the transfer of these assets can be likened to a grant. Based on the grant procedure and Minister of Home Affairs Circular No. 120/5935 / SJ taggal 16 October 2015 concerning the Acceleration of the Implementation of the Transfer of Affairs based on Law No. 23/2014 can be seen from the rights and obligations / duties of local governments. The Surabaya City Government and the province have the task of forming an Asset Inventory Team in the context of an inventory as well as recording completeness of asset status 
This work is licensed under a Creative Commons Attribution-ShareAlike 4.0 International License

data along with proof of ownership documents. Coordination is also carried out between the Asset Inventory Team, the Education Office, and the BPKAD in order to evaluate, reconcile and verify valid data on the assets to be transferred. Then proceed with the signing of the MoU along with the handover accompanied by BAST Assets. As a follow-up, the Surabaya City Government wrote off the transferred assets in the financial statements, while the Provincial Government recorded the assets received from the City of Surabaya in the financial statements. With regard to the legal status of its maintenance, BAST is a document of handing over of goods as evidence of delivery and transfer of rights / ownership of assets from the donor to the recipient of the assets. Juridically, these assets were transferred from the Surabaya City government to the provincial government.

This transfer of asset management can be carried out because it is a law order. Even though Article 37 paragraph (1) states that the transfer of rights to land and property rights can only be registered if it is proven by a deed made by the authorized PPAT according to the provisions of the prevailing laws and regulations. However, based on the Circular of the Minister of Agrarian Affairs and Spatial Planning / Head of the National Land Agency Number: 1855 / 15.1 / IV / 2016 dated April 22, 2016 concerning Guidelines for Implementing Land Registration for Government Agencies, so that government agencies in this case the East Java provincial government have a specificity (Lex Specialis Derogat Legi Generalis) and facilities in order to obtain rights and settle certificates for the lands which are its assets.

Constraints found in the transition process in secondary education are generally administrative constraints, namely the occurrence of errors between the inventory data and the actual conditions in the field. In addition, there are still several cities in Surabaya that do not understand the objects that are included as intermediate objects of secondary education. To overcome this humbtaan, the East Java Provincial Education Office took systematic action. That is, the action does not only include solving the problem in one aspect, but covers all four aspects as a whole. The Field Verification Team and the Regional Assistance Team have a central role in overcoming problems related to the transition to the Secondary Education sector, namely by recorrecting the results of data collection and confirming the results of data collection both to the Surabaya City education office concerned and to the East Java Provincial Education Office. .

\section{REFERENCES}

Aira, A. (2015). The role of asset management in regional development. Kutubkhanah, 17(1), 2139.

Damayanti, R. (2012). SECTION OF REGIONAL AUTONOMY AFFAIRS TO SUB-DISTRICTS BASED ON REGULATION OF THE MAYOR OF SURABAYA NUMBER 29 OF 2009. AIRLANGGA UNIVERSITY. 
Damayanti, SN (2017). Prospective Analysis of the Policy on the Transfer of Secondary Education Authority from the Surabaya City Government to the East Java Provincial Government Based on Law no. 23 of 2014 concerning Regional Government. Public Policy and Management, $5(3), 1-12$.

Indonesia, PR (2003). Law of the Republic of Indonesia number 20 of 2003 concerning the national education system. Jakarta: Government of the Republic of Indonesia.

INDONESIA, PR (2014). Republic of Indonesia Government Regulation Number 27 of 2014 concerning State / Regional Property Management.

Istiningsih, I. (2019). LEGAL CONSEQUENCES CONCERNING THE TRUTH OF THE CONTENT OF PPAT ASSETS, TRANSACTION PRICES AND ASSET DATES AFTER THE IMPLEMENTATION OF TAX VALIDATION IN BOYOLALI DISTRICT. Sultan Agung Islamic University.

Kahfi, S. (2016). Transfer of Management of Regional Property in the Form of Land in the Implementation of Senior High School Education in Lampung Province. Fiat Justisia: Journal of Legal Studies, 10(4), 681-696.

Nurhayati, Y. (2013). The Debate Between Normative Methods and Empirical Methods in Legal Studies Research in terms of the Character, Function, and Objectives of Law Science. Al-Adl: Journal of Law, 5(10).

PAMUNGKAS, J. (nd). SAP APPLICATION ANALYSIS NO. 07 (FIXED ASSETS) AND BULTEK NO. 09 ON VEHICLES OF EDUCATION AND TRAINING AGENCIES OF WEST KALIMANTAN PROVINCE. Journal of Scientific Study of Accounting, Faculty of Economics UNTAN (KIAFE), 4(4).

Panjaitan, DAT, \& Budi Gutami, S. (2017). Juridical Analysis of Transition of Secondary Education Sector from District / City Government to Provincial Government as Implementation of Law Number 23 Year 2014 concerning Regional Government. Diponegoro Law Journal, 6(2), 1-19.

Puteri, O. (2018). The Politics of Decentralization: Implications of Withdrawing the Authority of Education Management for Senior High Schools and Equals in the City of Surabaya. Airlangga University.

Safa'at, MA, \& Number, U.-U. (2016). Constitutionality of Transfer of Authority for Secondary Education Management from Districts / Cities to Provinces. Paper Presented as Expert Statement at the Constitutional Court Session of the Republic of Indonesia, Case Number, 30. 